\title{
Doding gevolgd door zelfdoding in Nederland
}

\author{
Marieke Liem en Natascha van Keeken
}

MEM 91 (2): 133-151

DOI: 10.5117/MEM2016.2.LIEM

\begin{abstract}
Summary
Homicide followed by suicide in the Netherlands

Homicide followed by the suicide of the perpetrator often leads to shock and incomprehension. It has been suggested that media reporting on such cases could lead to an imitation effect. This article describes the nature and incidence of homicide-suicide in the Netherlands in the period 1992-2014. In addition, it assesses whether a copycat-effect can be established due to media reporting. Results show that homicide-suicides occur on average nine times per year. Intimate partner homicide-suicide and child homicide-suicide are the most frequent types of homicide-suicide. Even though several temporal clusters could be observed during the period of study, there are insufficient indications to confirm a copycat-effect. This may be attributed to the heterogeneous and multifaceted nature of this phenomenon, lacking one single potentially 'contagious' cause.
\end{abstract}

Keywords: Homicide, suicide, homicide-suicide, murder-suicide, epidemiology, copycat-effect

\section{$1 \quad$ Inleiding}

Doding gevolgd door zelfdoding is een incident waarin een dader één of meerdere slachtoffers maakt, alvorens de hand aan zichzelf te slaan. In de meeste gevallen gaat het bij doding-zelfdoding om een man die zijn eigen familieleden doodt en daarna een eind aan zijn eigen leven maakt (Barber, Azrael, Hemenway, Olson, Nie, Schaechter \& Walsh, 2008; Liem \& Nieuwbeerta, 2010). De meest voorkomende typen vormen de combinaties kinderdoding-zelfdoding, partnerdoding-zelfdoding en gezinsdoding-zelfdo- 
ding, in de volksmond ook wel bekend als 'familiedrama's'. Dergelijke zaken hebben een grote maatschappelijke impact: Neem bijvoorbeeld de recente zaak waarin de twee broertjes Ruben en Julian om het leven werden gebracht door hun vader, die hierop volgend een einde aan zijn leven maakte, of een zaak in Etten-Leur waarin een 41-jarige vader zijn stiefzoon en dochter doodde, voordat hij overging tot zelfdoding.

Verschillende media hebben geopperd dat doding-zelfdoding een relatief nieuw fenomeen is, dat steeds vaker voorkomt. Aangezien deze zaken vaak uitgebreid worden gerapporteerd in de media, zou dit tot imitatiegedrag kunnen leiden - men zou zich kunnen herkennen in de dader en in diens problematiek en zou de doding-zelfdoding als voorbeeld kunnen nemen (Brants \& Koenraadt, 1998). Het is tot nu toe onbekend in hoeverre de aard en incidentie van doding gevolgd door zelfdoding is toe te schrijven aan een mogelijk copycat-effect.

Het doel van dit artikel is om een overzicht te geven van doding-zelfdoding in Nederland in de afgelopen decennia. Daarnaast pogen we te onderzoeken of er ook daadwerkelijk sprake is van een copycat-effect onder dit type doding. Voor deze studie zal gebruik worden gemaakt van een speciale database van alle incidenten van doding gevolgd door zelfdoding in de periode 1992-2014.

\section{$1.1 \quad$ Incidentie}

Doding-zelfdoding is een zeldzaam fenomeen (Liem \& Koenraadt, 2007) en de incidentie van doding-zelfdoding verschilt sterk van land tot land. Eerder onderzoek laat zien dat doding-zelfdoding varieert van $42 \%$ van het totaal aantal dodingen in Denemarken (West, 1965) tot 1,5\% van alle dodingen in de Verenigde Staten (Berman, 1979). Onderzoek in het Verenigd Koninkrijk wijst uit dat doding-zelfdoding ongeveer 1 tot $7 \%$ van alle dodingen bedraagt (Barraclough \& Clare Harris, 2002). In Nederland is tot dusver gekeken naar de incidentie van doding-zelfdoding in de periode van 1992-2006. Doding-zelfdoding bedroeg in deze periode ongeveer $4 \%$ van alle dodingen (Liem, 2010).

\subsection{Classificatie}

Doding-zelfdodingen worden voornamelijk gecategoriseerd op basis van de vijf meest voorkomende relaties tussen dader en slachtoffer, bestaande uit partnerdoding-zelfdoding, kinderdoding-zelfdoding, gezinsdoding-zelfdoding, doding van overige familieleden gevolgd door zelfdoding en tot slot de doding van niet-familieleden gevolgd door zelfdoding (Liem, Postulart \& Nieuwbeerta, 2007; Marzuk et al., 1992). De twee laatstgenoemde 
typen doding-zelfdoding zijn relatief schaars en vertonen geen sterke interne samenhang. We zullen daarom nader aandacht besteden aan de drie meest voorkomende vormen: partnerdoding-zelfdoding, kinderdodingzelfdoding en gezinsdoding-zelfdoding.

\subsubsection{Partnerdoding gevolgd door zelfdoding}

Onderzoek naar doding-zelfdoding wijst uit dat partnerdoding gevolgd door zelfdoding het meest voorkomende type is van doding-zelfdodingen. Mannen zijn de voornaamste daders, die hun (ex-)partner doden met een vuurwapen (Barber et al., 2008; Saint-Martin et al., 2007) of steekwapen (Liem \& Oberwittler, 2013). Daders van partnerdoding-zelfdodingen zijn ouder dan daders die geen zelfmoord plegen na de doding. Een verklaring die hier voor wordt gegeven is de aanwezigheid van psychiatrische stoornissen: de frequentie van psychiatrische stoornissen neemt toe naarmate men ouder wordt. Ook zijn oudere daders langere tijd in staat geweest een intieme relatie op te bouwen met het slachtoffer (Felthous \& Hempel, 1995).

In de literatuur worden partnerdoding-zelfdodingen opgesplitst in twee verschillende groepen. Bij de eerste groep is er sprake van een pathologische vorm van bezitsdrang (Liem \& Oberwittler, 2013). Volgens dit perspectief hebben mannen de neiging om vrouwen te beschouwen als een seksueel 'eigendom' dat zij kunnen bezitten. Wanneer zij controle over dit 'eigendom' verliezen door bijvoorbeeld ontrouw, kunnen zij overgaan tot fataal geweld in een laatste poging controle te behouden over hun vrouw (Daly \& Wilson 1988). Bij deze groep is er in het verleden vaak al sprake geweest van huiselijk geweld (Starzomski \& Nussbaum, 2000).

De tweede groep bestaat vooral uit oudere daders en slachtoffers, waarbij niet zelden wordt gesproken van een 'zelfdodingspact', waarmee de suggestie wordt gewekt dat beide partners in onderlinge overeenstemming een einde aan hun beider levens maken. In deze gevallen is er meestal ziekte of achteruitgang van de gezondheid van één of beide partners in het spel. Nadere bestudering van zelfdodingspacten laat veelal zien dat één van de partners de ander aanspoort om zichzelf van het leven te beroven, of meeneemt in de eigen dood (Liem, Postulart \& Nieuwbeerta, 2007; van Wijngaarden et al., 2015).

\subsubsection{Kinderdoding gevolgd door zelfdoding}

Kinderdoding-zelfdoding vormt, op partnerdoding-zelfdoding na, het meest voorkomende type doding-zelfdoding (Liem, Postulart \& Nieuwbeerta, 2007; Liem, 2010; West, 1965). Ook dit type doding-zelfdoding kan worden opgedeeld in twee verschillende groepen. 
De eerste groep betreft de extended suicide. Hier worden kinderen gezien als een verlengd deel van de ouder. De ouders zijn van mening dat er niemand meer kan zorgen voor de kinderen wanneer zij er niet meer zijn, waardoor zij besluiten de kinderen mee te nemen in de dood. Dit wordt ook wel het 'pseudo-altruïstische' motief genoemd. Immers, het is slechts vanuit het oogpunt van de ouder bezien het 'beste' indien het slachtoffer wordt meegenomen in de dood (Liem, 2010). Eerder onderzoek laat zien dat dergelijke delicten vooral door vrouwen worden gepleegd en worden gekarakteriseerd door gevoelens van hulpeloosheid en uitzichtloosheid (Liem \& Koenraadt, 2008a).

Bij de tweede groep kinderdoding-zelfdoding wordt het kind gedood om wraak te nemen op de partner. Mannen, doorgaans dertigers en veertigers, zijn de voornaamste daders van deze delicten, hetgeen kan worden verklaard uit het feit dat niet zij, maar hun vrouwelijke partner de kinderen krijgt toegewezen na een scheiding. In dergelijke gevallen wordt de agressie richting de partner gericht op de kinderen (Liem, 2010). Dit fenomeen wordt ook wel het 'Medea-complex' genoemd, vernoemd naar de Griekse mythe waarin Medea haar ex-partner Jason wilde straffen door hun beider kinderen te doden (Liem, Postulart \& Nieuwbeerta, 2007; Liem, 2010).

\subsubsection{Gezinsdoding gevolgd door zelfdoding}

De derde meest voorkomende categorie bestaat uit een combinatie van partnerdoding en kinderdoding, de zogenaamde gezinsdoding ('familicide') gevolgd door zelfdoding. Dit type doding wordt eveneens vooral door mannen gepleegd (Léveillée et al., 2007; Liem, Levin, Holland \& Fox, 2013; Liem \& Koenraadt, 2008b), hetgeen kan worden verklaard door de veronderstelling dat mannen hun vrouwen en kinderen als 'eigendom' zien, die slachtoffer gemaakt worden wanneer zij hun patriarchale status dreigen te verliezen (Daly and Wilson, 1988; Wilson et al., 1995). Net als bij kinderdoding kan ook bij gezinsdoding een tweedeling worden gemaakt van zaken waarin mannen besluiten hun gezinsleden 'mee te nemen' naar het hiernamaals, en zaken waarin woede en agressie richting de partner de hoofdrol spelen. Hierbij worden kinderen opnieuw beschouwd als verlengstuk van de partner en tevens tot slachtoffer gemaakt (Liem \& Koenraadt, 2008b).

\subsection{Het copycat-effect}

Er wordt in de media vaak uitgebreid bericht over incidenten van dodingzelfdoding, met name wanneer daarbij kinderen zijn betrokken. Er is geopperd dat deze uitvoerige berichtgeving mensen op ideeën zou brengen 
om een soortgelijk delict te begaan (Helfgott, 2015; Wijfjes, 1997). Zo pleitte in 1997 hoogleraar Wim Wolters voor een mediastilte rondom incidenten van kinderdoding. Een aantal van deze kinderdodingen resulteerde in zelfdoding van een ouder. Volgens Wolters was de toenemende groei van kinderdodingen te wijten aan berichtgeving in de media, hetgeen volgens hem zou leiden tot imitatiegedrag (Wijfjes, 1997). Brandts \& Koenraadt (1998) gaven echter aan dat er weliswaar sprake was van een epidemie in de mediaberichtgeving, maar dat zij het onverantwoord vonden om te spreken over een daadwerkelijke 'epidemie', gezien de kleine aantallen kinderdodingen per jaar. Een verband tussen de 'mediahype' en incidenten van kinderdodingen werd niet bewezen.

Hernieuwde aandacht voor het onderwerp kwam in 2007, toen Jaap Smit, de directeur van Slachtofferhulp, vroeg om terughoudendheid in de informatie die verstrekt wordt door de media over incidenten met betrekking tot doding-zelfdoding. Slachtofferhulp deed deze oproep naar aanleiding van twee incidenten van doding gevolgd door zelfdoding in één week. Uitgebreide informatie over deze incidenten zou mensen op ideeën kunnen brengen. Zijn standpunt werd destijds gesteund door hoogleraar suïcidepreventie Ad Kerkhof (Elsevier, 2007).

Het idee dat mediaberichtgeving kan aanzetten tot 'copycat-gedrag' is niet nieuw. In 1974 kwam David Phillips op de term 'Werther-effect' voor copycat-zelfdodingen die volgen na een zelfdoding die uitgebreid in de media is geweest (Phillips, 1974). Deze term is ontstaan naar aanleiding van Goethes briefroman Die Leiden des jungen Werthers uit 1774. Hierin ging de hoofdpersoon Werther over tot zelfdoding toen duidelijk werd dat hij nooit een relatie zou kunnen hebben met de vrouw die hij beminde. Kort na de publicatie van het boek volgde er een golf van zelfdodingen in Europa, met name onder jonge mannen die zich identificeerden met de hoofdpersoon. Velen van hen imiteerden Werther's kleding (een blauwe colbert met geel gilet) en zelfdodingsmethode (vuurwapen) (Haw et al., 2013).

Ondersteuningen voor het copycat-effect zijn gemengd: sommige internationale studies bevestigen een dergelijk effect inzake zelfdoding (Frei, Schenker, Finzen, Ditmann, Kraeuchi \& Hoffman-Richter, 2003; Jae-Hyun, Park, Nam, Park, Cho, Kim, Choi, Cho \& Mesoudi, 2013; Schmidtke \& Häfner, 1988; Wasserman, 1984), terwijl uit nationaal onderzoek een verband tussen publicatie en zelfdodingscijfers ontbreekt. Zo bleek uit een studie van Köpping en collega's (1989) dat er geen significante relatie was te ontdekken tussen de kenmerken van de berichtgeving - zoals illustraties, type krant, bekendheid van het slachtoffer, methode en suggestiviteit 
van het bericht - en het aantal verwachte suïcides volgend op de publicatie van het bericht.

In eerder internationaal onderzoek waar wel een verband wordt gevonden tussen publicaties over suïcides en de daaropvolgende incidentie van suïcides, wordt gesteld dat een suïcidecluster zich gedraagt als een epidemie (Haw e.a., 2013). Zo blijkt dat een copycat-effect het grootst is in de korte periode na het oorspronkelijke incident, waarin sommige onderzoekers drie dagen (Cheng e.a., 2011) en anderen een week aanhouden (Clarke \& McGrath, 1992; Phillips, 1974). Tevens wijst de literatuur uit dat het copycat-effect het sterkst is wanneer het geslacht en de te kiezen methode van de gepubliceerde zelfdoding overeen komen (Niederkrotenthaler e.a., 2009; Fu and Yip, 2009). In tal van publicaties wordt doding-zelfdoding als een apart type zelfdoding gezien, waarin de dader het slachtoffer 'meeneemt' in de eigen dood (Marleau, Poulin, Webanck, Roy \& Laporte, 1999; Messing \& Heeren, 2004). Vanuit dit perspectief vormt doding-zelfdoding geen apart gedragskundig fenomeen, maar louter een variatie op zelfdoding. Tot dusver is het echter niet bekend in hoeverre het copycat-effect is waar te nemen bij doding-zelfdoding. Naast deze wetenschappelijke relevantie, is het van maatschappelijk belang te weten of en hoe potentiële daders van doding-zelfdoding kunnen worden 'aangestoken' door berichtgeving over deze zaken, om zo eventuele copycats in de toekomst te voorkomen.

\section{$2 \quad$ Methoden}

\subsection{Data}

Voor deze studie is er gebruik gemaakt van een speciale database van alle incidenten van doding gevolgd door zelfdoding in de periode van 19922014. Hierin zijn ook incidenten opgenomen van doding gevolgd door een serieuze poging tot zelfdoding. Bij een poging heeft de dader weliswaar de intentie om zichzelf van het leven te beroven, maar slaagt hier niet in. Deze definitie volgt diverse internationale studies (Barber et al., 2008; Flynn, et al., 2009). De voor deze studie samengestelde database bestaat uit een aantal bronnen, waarbij de bestaande database Homicide-Suicide 19922006 (Liem, 2010; Liem \& Koenraadt, 2007) is uitgebreid tot en met 2014, om zo een actueel beeld te kunnen geven.

De voor dit artikel hernieuwde database Homicide-Suicide 1992-2014 bevat zaak-, slachtoffer- en daderinformatie afkomstig uit de Moord-en Doodslaglijsten van Elsevier, een veelgebruikte overzichtsbron bij moord 
en doodslagonderzoek (zie Nieuwbeerta \& Leistra, 2007; Leistra \& Nieuwbeerta, 2003).

Vervolgens hebben we deze gegevens aangevuld met informatie uit nieuwsberichten. Voor de periode 1992-2006 hebben we papieren archieven van nationale en regionale kranten geraadpleegd (Liem \& Koenraadt, 2007). Voor de periode 2007-2014 hebben we via Google News gezocht naar krantenberichten over de desbetreffende incidenten. Hierbij werd gezocht op datum, de plaats waar de doding had plaatsgevonden, en het type doding.

Voorts hebben we deze informatie gevalideerd aan de hand van politiegegevens afkomstig uit de Basis Voorziening Handhaving (BVH), ontsloten in COGNOS, het managementinformatiesysteem van de Nederlandse politie. Binnen de BVH worden meldingen geregistreerd, aangiftes verwerkt en incidenten afgehandeld. Met medewerking van het Bureau Management Informatie Nationale Politie werd politiedata omtrent levensdelicten verstrekt, met als inclusiecriteria moord, doodslag en zware mishandeling de dood ten gevolge hebbende. Met uitzondering van zes zaken, kwamen alle doding-zelfdodingen die in de onderzochte periode in de media werden gerapporteerd, tevens voor in de politiedata. Onderrapportage in de politiedata is mogelijk toe te schrijven aan één van de volgende factoren: (a) De classificatie van delicten. Zo kwam een doding-zelfdoding door middel van een auto niet voor - mogelijk is deze geclassificeerd als een autoongeluk en zodanig niet meegenomen in de data. Hetzelfde geldt voor een aangestoken dodelijke brand die de levens eiste van de dader, zijn vrouw en hun drie kinderen. (b) Zaken die nog als niet-afgesloten worden beschouwd en daarom niet gedeeld konden worden ten behoeve van onderzoek.

Tot slot is de database uitgebreid met rapportagemateriaal vanuit het Pieter Baan Centrum. Dit betrof voornamelijk zaken die betrekking hadden op kinderdoding gevolgd door bijna-zelfdoding: de verdachte had de poging tot zelfdoding overleefd en werd vervolgens in het kader van de Rapportage pro Justitia in het centrum onderzocht (zie Liem, Koenraadt \& Hengeveld, 2009; Liem \& Koenraadt, 2007; Liem, 2010).

\subsection{Analyse}

Om een beeld te schetsen van de incidentie van doding gevolgd door zelfdoding hebben we gebruik gemaakt van beschrijvende statistiek. Vanwege het relatief klein aantal doding-zelfdodingen passen we geen toetsende analyses toe zoals gebruikt in suïcide-onderzoek (Köpping e.a. 1989; Phillips, 1974). Als gedurende de onderzoeksperiode bepaalde periodes signifi- 
cant meer doding-zelfdodingen kennen dan het gemiddelde, worden de casussen ervan uit die jaren nader onder de loep genomen, door afzonderlijk te kijken naar de kenmerken van de doding-zelfdodingen. Om een eventueel copycat-fenomeen vast te stellen, hebben we allereerst gekeken naar factoren uit eerder onderzoek naar suïcideclusters. Hierbij hebben we bekeken of zaken (a) kort na elkaar plaatsvonden (gezien de lage prevalentie van doding-zelfdoding binnen een periode van drie weken); (b) eenzelfde methode kenden; (c) vergelijkbare dader- en slachtofferkarakteristieken hadden; (d) en of er sprake was van overeenkomstige motieven. Deze werden vervolgens met elkaar vergeleken.

\section{Resultaten}

In de periode 1992-2014 hebben er 204 incidenten van doding gevolgd door zelfdoding plaatsgevonden. In 48 gevallen was er sprake van doding gevolgd door een poging tot zelfdoding. In deze zaken heeft de dader wel getracht zelfdoding te plegen na het delict, maar is hier niet in geslaagd. In totaal zijn er 205 daders en 284 slachtoffers opgenomen in de database. Dit betreft zowel doding gevolgd door zelfdoding als doding gevolgd door een ernstige poging tot zelfdoding.

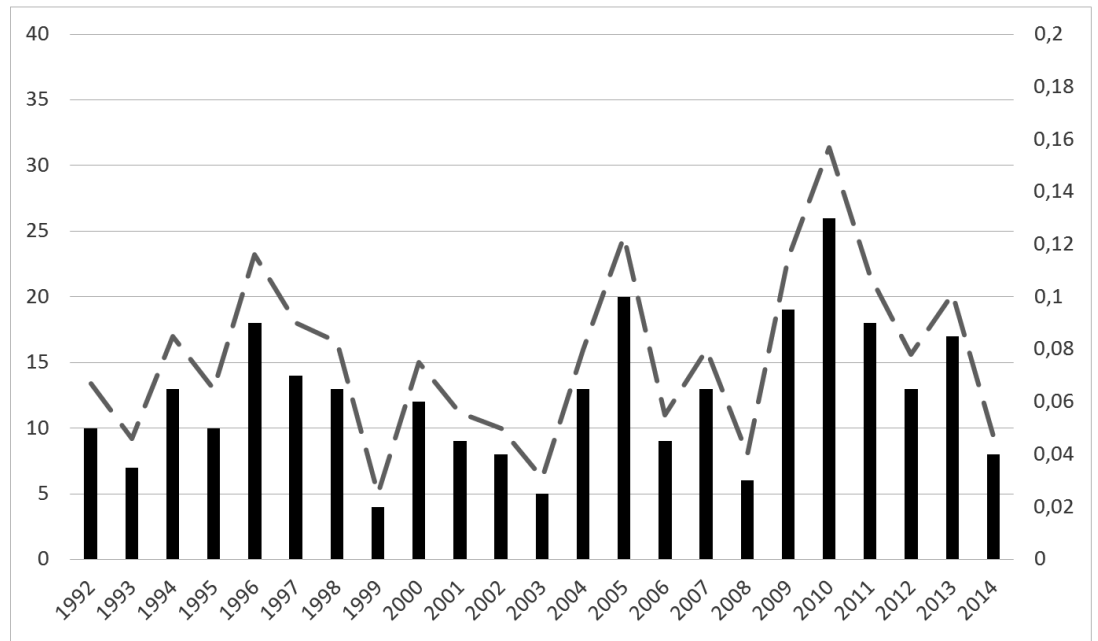

Figuur 1 Overzicht aantal doding-zelfdodingen per jaar inclusief slachtofferratio 1992-2014 
Het jaarlijks aantal slachtoffers van doding gevolgd door zelfdoding is tijdens de onderzochte periode relatief gelijk gebleven. De hoogste aantallen zijn te vinden in de periodes 1994-1998 en 2009-2013. Het jaar 2010 kent het hoogste aantal slachtoffers: 26 in totaal.

In de onderzochte periode varieerde de ratio doding-zelfdodingen van 0,025 per 100.000 tot 0,15 per 100.000 . Momenteel ligt het percentage doding-zelfdodingen op $7 \%$ van het totaal aantal dodingen, ofwel een slachtofferratio van 0,077 per 100.000 inwoners. Nederland vormt met deze ratio een internationaal gemiddelde.

Hoewel het aantal doding-zelfdodingen relatief constant blijft, neemt het totaal aantal levensdelicten sinds 2006 af (zie voor details: Liem, Smit, Van Wilsem \& Nieuwbeerta, 2012; Liem \& Leissner, 2016). Hierdoor neemt het relatieve percentage dodingen dat eindigt in de zelfdoding van de dader toe: van 4,6\% van alle dodingen in de jaren '9o tot $7,6 \%$ van alle dodingen in de afgelopen jaren.

Wanneer we specifiek kijken naar de periode in het jaar, blijkt dat doding-zelfdoding relatief vaak in januari voorkomt (13\% van het totaal), vergeleken met de zomermaanden juni tot en met september (6 à $7 \%$ ). Met betrekking tot dagen van de week zien we dat zaken iets vaker plaatsvinden op zondag $(16 \%)$ en maandag $(17 \%)$ vergeleken met andere dagen in de week. Voor zover bekend vinden zaken iets vaker 's ochtends (16\%) plaats vergeleken met andere tijdstippen op de dag.

Tabel 1 Plaats delict, type en modus operandi doding-zelfdodingen in Nederland, 1992-2014 ( $=204)$

\begin{tabular}{lll}
\hline Plaats delict & Aantal & Percentage \\
$\begin{array}{l}\text { Privéwoning van slachtoffer en } \\
\text { dader }\end{array}$ & 92 & 45 \\
$\begin{array}{l}\text { Privéwoning van dader } \\
\text { Privéwoning van slachtoffer }\end{array}$ & 18 & 9 \\
Winkel, restaurant etc. & 35 & 17 \\
Straat, openbaar vervoer etc. & 11 & 5 \\
Anders & 13 & 6 \\
Onbekend & 17 & 8 \\
& 18 & 9 \\
\hline Type doding & & \\
\hline Partnerdoding & Aantal & Percentage \\
Kinderdoding & 127 & 47 \\
Andere familiedoding & 107 & 40 \\
Doding buiten familie & 7 & 3 \\
Onbekend & 29 & 10 \\
\hline
\end{tabular}




\begin{tabular}{lll}
\hline Modus operandi & Aantal & Percentage \\
Vergiftiging & 12 & 5 \\
Verhanging, wurging, verstikking & 44 & 19 \\
Vuurwapen & 80 & 34 \\
Mes of ander scherp wapen & 68 & 29 \\
Stomp wapen & 10 & 4 \\
Duwen & 8 & 3 \\
Motorvoertuig & 8 & 3 \\
Anders & 7 & 3 \\
Onbekend & 47 & \\
\hline
\end{tabular}

Veruit de meeste zaken van doding zelfdodingen vinden plaats in de gezamenlijke privéwoning van dader en slachtoffer $(45 \%)$. Ook de privéwoning van het slachtoffer komt relatief vaak voor $(17 \%)$. Daarnaast is doding-zelfdoding zowel een stedelijk als een landelijk fenomeen. Driekwart van alle doding-zelfdodingen vinden in een stedelijk gebied plaats. Dit is ook terug te zien bij andere typen moorden: zo vond in de periode 2009-2014 het merendeel van alle moorden in Nederland plaats in grootstedelijke gebieden. Daarbij werd ongeveer één op de drie moorden gepleegd in de drie grootste steden, Amsterdam, Rotterdam en Den Haag (Liem \& Leissner, 2016).

Bijna alle doding-zelfdodingsincidenten vinden binnen het gezin plaats, waarbij partnerdoding gevolgd door zelfdoding het meeste voorkomt met 127 slachtoffers (47\%). Kinderdoding is de tweede meest voorkomende vorm van doding-zelfdoding met 107 slachtoffers (40\%). Doding-zelfdoding buiten de familie vindt in 10\% van de gevallen plaats (zie tabel 1). In alle categorieën zijn mannen de voornaamste daders: $99 \%$ van de partnerdoding-zelfdodingen is door mannen gepleegd, $60 \%$ van de kinderdodingzelfdodingen, $67 \%$ van de gezinsdoding-zelfdodingen, $100 \%$ van de overige familiedoding-zelfdodingen en $91 \%$ van de doding-zelfdodingen buiten het gezin. Het meest voorkomende wapen in deze delicten vormt een vuurwapen, gevolgd door een mes of ander scherp wapen (zie tabel 1).

Het tijdstip waarop de dader zelfmoord pleegt is in een groot deel van de zaken onbekend. Voor zover bekend maken de meeste daders van deze delicten direct na de doding een einde aan hun eigen leven. Net als bij de doding komen bij zelfdoding als modus operandi vuurwapens, messen en verhanging/ verstikking het meest voor. Het wapen dat gebruikt is tijdens de moord wordt vaak tevens gebruikt tijdens de zelfdoding. Een uitzondering betreft zelfdoding door van een gebouw af te springen of door voor een trein springen.

De meest voorkomende motieven voor doding-zelfdoding bestaan uit ernstige psychische stoornissen $(28 \%)$, scheidingen $(22 \%)$ en pseudo-altruïsme $(16 \%)$ (zie tabel 2). De meerderheid van de slachtoffers is van het 
vrouwelijk geslacht (zie tabel 3). Ruim één derde van de slachtoffers zijn kinderen onder de 14 jaar. De daarop volgende grootste leeftijdscategorie voor slachtoffers is 30 tot 49 jaar $(29 \%)$. De daders van doding-zelfdoding zijn bijna allen van het mannelijk geslacht. Veruit de meeste daders vallen in de leeftijdscategorie van 30 tot 49 jaar $(60 \%)$.

Tabel 2 Motieven van doding-zelfdodingen in Nederland, 1992-2014 ( $N=269)$

\begin{tabular}{lll}
\hline Motief & Aantal & Percentage \\
\hline Wraak & 20 & 14 \\
Scheiding & 31 & 22 \\
Psychische stoornis & 39 & 28 \\
Altruïsme & 23 & 16 \\
Economisch & 8 & 6 \\
Ander motief & 19 & 14 \\
Motief onbekend & 129 & \\
\hline
\end{tabular}

Tabel 3 Slachtofferkenmerken doding-zelfdodingen in Nederland, 1992-2014 (N = 284)

\begin{tabular}{lll}
\hline Geslacht slachtoffer & Aantal & Percentage \\
Man & 100 & 35 \\
Vrouw & 184 & 65 \\
& & \\
\hline Leeftijd slachtoffer & Aantal & Percentage \\
$<14$ & 101 & 36 \\
$15-29$ & 47 & 17 \\
$30-49$ & 82 & 29 \\
$50-64$ & 29 & 10 \\
$65+$ & 20 & 8 \\
Onbekend & 5 & \\
\hline
\end{tabular}

Tabel 4 Daderkenmerken doding-zelfdodingen in Nederland, 1992-2014 $(\mathrm{N}=205)$

\begin{tabular}{lll}
\hline Geslacht dader & Aantal & Percentage \\
\hline Man & 171 & 84 \\
Vrouw & 32 & 16 \\
Onbekend & 2 & \\
& & \\
\hline Leeftijd daders & Aantal & Percentage \\
-14 & 3 & 2 \\
$15-29$ & 32 & 16 \\
$30-49$ & 120 & 60 \\
$50-64$ & 32 & 16 \\
65 & 13 & 6 \\
Onbekend & 5 & \\
\hline
\end{tabular}




\subsection{Clusters}

Het jaarlijks gemiddelde voor doding-zelfdoding ligt op negen zaken. Wanneer we deze opsplitsen in de verschillende categorieën vormt dit een gemiddelde van twee kinderdodingen, één gezinsdoding en vier partnerdodingen. Gezien het kleine aantal gezinsdodingen hebben we, om de analyse te vergemakkelijken, kinderdoding en gezinsdoding samengevoegd. Gezins- en kinderdoding vormen tezamen dus een gemiddelde van drie doding-zelfdodingen.

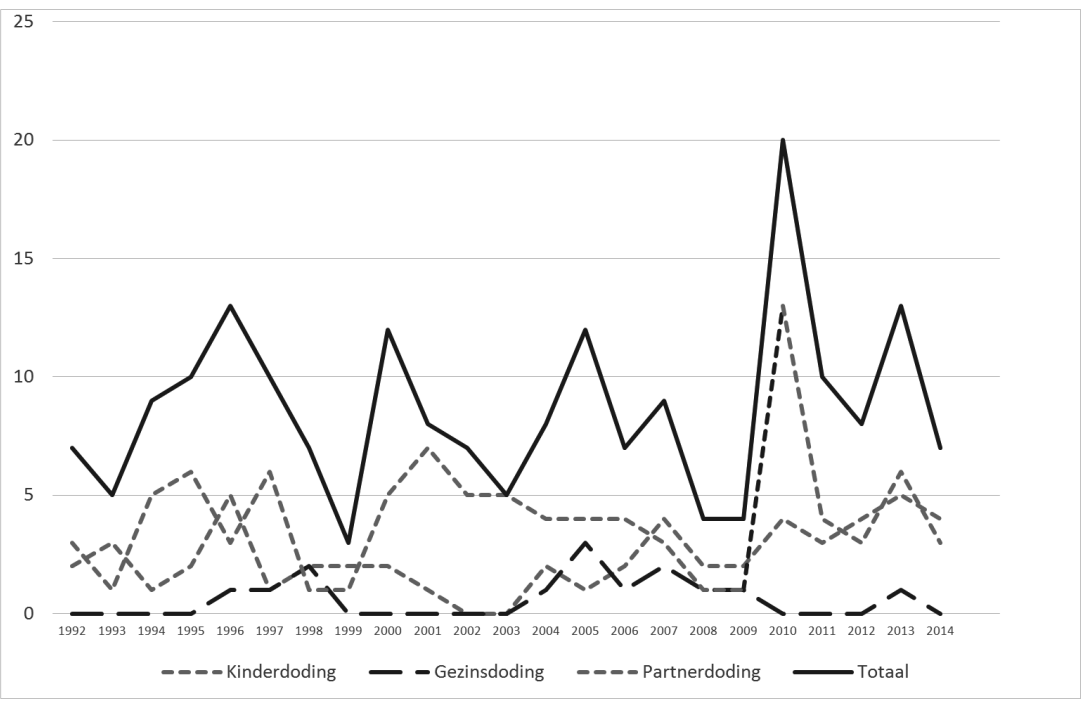

Figuur 2 Doding-zelfdoding in Nederland per type 1992-2014 $(N=204)$

De jaren 1996, 2000, 2005, 2007, 2010 en 2013 wijken af van het gemiddelde aantal te verwachten zaken, wat neerkomt op ofwel meer dan elf partnerdodingen ( $\mathrm{SD}=7.28)$, ofwel meer dan acht kinderdodingen en gezinsdodingen $(S D=5 \cdot 57)$. Door het gering aantal observaties houden we het hier bij beschrijvende statistiek. In de jaren 2000 en 2005 wordt deze afwijking voornamelijk veroorzaakt door andere doding-zelfdodingen dan de typen die wij hier onderzoeken, zoals doding-zelfdoding tussen onbekenden of tussen vrienden. Aangezien bij deze zaken geen samenhang is vast te stellen tussen dader en slachtoffer, zoals bij kinderdoding, partnerdoding of gezinsdoding het geval is, richten we ons stapsgewijs op de clusters die we hebben gevonden in 1996, 2007, 2010 en 2013. Hierbij kijken we achtereenvolgens naar (a) de tijdspanne waarin de zaken plaatsvonden; (b) de gebruikte methode; (c) vergelijkbare dader- en slachtofferkarakteristieken; (d) overeenkomstige motieven. 
Het jaar 1996 liet een cluster van kinderdodingen gevolgd door zelfdoding zien. Dit jaartal is al eerder genoemd in het artikel naar aanleiding van de oproep voor mediastilte rondom kinderdodingen (Wijfjes, 1997; Brandts \& Koenraadt, 1998). In dat jaar vonden zes doding-zelfdodingen plaats waarin kinderen het slachtoffer werden. Met uitzondering van twee zaken in mei, die tien dagen na elkaar plaatsvonden, vonden alle overige zaken verspreid over het kalenderjaar plaats, zonder duidelijke concentratie. Deze twee zaken verschilden drastisch van elkaar in methode, dader- en slachtofferkarakteristieken en motief: de eerste betrof een 37-jarige vader, die uit wraakgevoelens tegen zijn vrouw zijn drie kinderen (van zeven, acht en tien) trachtte te doden door hen neer te steken, na hen slaappillen te hebben toegebracht. Tien dagen later bracht een 38-jarige moeder met psychische problemen haar 4-jarige zoontje om het leven door verwurging. In geen van beide zaken werd over de zelfdodingsmethode gerapporteerd.

Voorts hebben we nader gekeken naar het cluster in 2007 waarin zeven zaken plaatsvonden waar kinderen bij betrokken waren. Twee van deze zaken betroffen gezinsdoding-zelfdodingen, die binnen een week van elkaar in maart plaatsvonden. De ene zaak betrof een 45 -jarige vader en een 44-jarige moeder, die samen uit pseudo-altruïstische overwegingen met medicatie hun zoontjes van negen en elf doodden alvorens een suïcidepoging te ondernemen. De man overleefde dit voorval. De zaak die een week later plaatsvond, betrof een 32-jarige vader die, gemotiveerd door relatieproblemen, zijn schoonmoeder doodde en vervolgens met zijn twee zoontjes van vier en zes voor de trein sprong.

Het tweede cluster dat jaar werd gevormd door twee zaken in oktober, die vijf dagen van elkaar plaatsvonden, maar inhoudelijk sterk verschilden: Een 37-jarige moeder doodde haar 16-jarige dochter door fysiek geweld. Hierna sprong zij voor de trein. Het motief bleef onbekend. Vijf dagen later gooide een verwarde vrouw haar dochtertje van de vierde etage van de Bijenkorf in Amsterdam en sprong haar achterna. Ze overleefde het voorval. Hoewel het geslacht van de daders overeenkwam, verschilden slachtofferkarakteristieken en motief drastisch van elkaar.

Het derde cluster zaken vond plaats in 2010. Dit cluster werd voornamelijk gekenmerkt door partnerdodingen: van de twintig zaken in dit jaar betroffen er dertien een partnerdoding gevolgd door zelfdoding. Opvallend is dat er weinig informatie (zoals over motief en methode) wordt vrijgegeven over deze zaken in nieuwsberichten. Dit jaar kende een cluster van zaken in de laatste week van februari en de eerste twee weken van maart. Eind februari stak een 29-jarige man zijn 26-jarige vriend dood en maakte na zijn arrestatie een einde aan zijn leven. Het motief bleef onbekend. In 
de eerste week van maart werd een 39-jarige vrouw gedood door haar 43jarige ex-partner, nadat zij kort daarvoor uit elkaar waren gegaan. De methode bleef onbekend. De derde zaak in dit cluster betrof een 37-jarige vrouw, die door haar 38-jarige partner werd doodgestoken. Hierna sprong hij van een flat af. Over het motief werd niet gerapporteerd.

Het tweede cluster dat jaar werd gevormd door partnerdoding-zelfdodingen die eind april en begin mei plaatsvonden: in de eerste zaak betrok het een 61-jarige vrouw die haar 69-jarige man doodde. Over de methode en het motief werd niets bekend gemaakt. De tweede zaak, ruim twee weken later, betrof een 56 -jarige man die zijn 46-jarige vrouw met een bijl om het leven bracht. Zij was een nieuwe relatie aangegaan. De zelfdodingsmethode bleef onbekend. De derde zaak in dit cluster betrof een 44-jarige Colombiaan die zijn 38-jarige vriendin doodde. Er was sprake van eerdere meldingen van huiselijk geweld. Zowel de dodingsmethode als de zelfdodingsmethode bleef onbekend.

Het derde cluster in 2010 betroffen zaken die eind juni, begin juli plaatsvonden. De eerste zaak betrof een 46-jarige Kaapverdiër man die zijn 40jarige vrouw doodde en daarna de hand aan zichzelf sloeg. Over de methode en motief werd niets bekend gemaakt. De tweede zaak vond twee dagen later plaats. Hier doodde een 66-jarige man zijn 61-jarige partner. Ook over deze zaak werden geen gegevens bekend gemaakt omtrent methode en motief. Iets minder dan twee weken later doodde een 38 -jarige man zijn 37-jarige vriendin met een onbekende methode.

Tot slot bestond het doding-zelfdoding cluster in 2013 hoofdzakelijk uit kinderdodingen gevolgd door zelfdoding: van de totaal dertien zaken betroffen er zes kinderdoding-zelfdodingszaken. Twee zaken vonden kort na elkaar plaats tussen eind april en begin mei. De eerste zaak betrof een 42jarige, psychotische moeder, die haar 7-jarige zoontje doodstak, waarna ze trachtte een einde aan haar leven te maken door haar polsen door te snijden. Iets meer dan twee weken later verdwenen twee jongetjes van 7 en 9, na door hun 38-jarige vader meegenomen te zijn. Men vermoedde dat de vader wraak wilde nemen op zijn ex-partner. De doodsoorzaak werd bij hun vondst niet bekendgemaakt.

\section{Discussie}

In dit onderzoek hebben we de aard en incidentie van doding gevolgd door zelfdoding in de periode van 1996-2014 in kaart trachten te brengen. Ons onderzoek is vooral beschrijvend van aard. Door het gebruik van politie- 
gegevens zijn we in staat geweest een betrouwbaar beeld te schetsen van dit fenomeen. Dit artikel geeft een overzicht van de epidemiologie van doding-zelfdoding, maar geeft geen inzicht in de psychische achtergrond van de verdachten van deze incidenten. Dit is toe te schrijven aan de gebruikte bronnen voor dit onderzoek: nieuwsberichten bevatten in sommige gevallen - zeker wanneer het kinderdoding betreft - uitgebreide achtergrondinformatie, terwijl in andere gevallen uiterst summier wordt gerapporteerd. Daarnaast bevatten de door ons gebruikte politiegegevens louter basale demografische gegevens over dader en slachtoffer(s), waarin informatie over de toedracht ontbreekt. Nader onderzoek naar de psychopathologische kenmerken van deze verdachten van doding-zelfdodingen kan mogelijkheden voor preventie aan het licht brengen.

Het percentage doding-zelfdodingen ligt momenteel op $7 \%$ van het totaal aantal dodingen. Dit vertaalt zich in een slachtofferratio van 0,077 per 100.000 inwoners. Internationaal gezien betreft dit een gemiddelde, vergelijkbaar met het Verenigd Koninkrijk (Liem, 2010), maar lager dan andere Europese landen zoals Finland (o,17 per 100.00o) (Kivivouri \& Lethi, 2003) en Zwitserland (o,09 per 100.000) (Liem, 2010).

De door ons gevonden patronen van doding-zelfdoding vertonen sterke overeenkomsten met andere Westerse landen: partnerdoding gevolgd door zelfdoding is de meest voorkomende type onder doding-zelfdoding, gevolgd door kinderdoding-zelfdoding (Panczak et al., 2013; Salari \& Sillito, 2016). Dit overzicht laat zien dat in de onderzochte periode de typen doding-zelfdodingen, de aard van de delicten en de modus operandi over de jaren heen relatief gelijk zijn gebleven. Een vuurwapen is nog steeds de meest gebruikte methode, gevolgd door een scherp wapen.

Veruit de meeste partnerdodingen gevolgd door zelfdoding werden begaan door mannen. Er is eerder geopperd dat vrouwen die hun partner doden, dit niet zelden doen als reactie op langdurig misbruik en zich na de doding bevrijd voelen van hun kweller (Swatt \& He, 2006). Zij gaan in dergelijke gevallen niet over tot suïcide, in tegenstelling tot mannen, die in sommige gevallen overweldigd worden door schuld, of door de wens hun partner alsnog in de dood te vergezellen.

Ook het merendeel van kinderdoding-zelfdodingen werd door mannen gepleegd, hetgeen overeenkomstig is met de bevindingen in eerdere internationale studies (Debowska et al., 2015; Sturup \& Granath, 2015). Dit kan worden toegeschreven aan het feit dat mannen een groter risico lopen op suïcide dan vrouwen (CBS, 2015), wellicht omdat zij dodelijker methoden toepassen dan vrouwen, en dus een hogere kans lopen te overlijden na een suïcidepoging vergeleken met vrouwen (Denning e.a. 2000). 
Overeenkomstig eerder onderzoek werd het merendeel van gezinsdodingzelfdodingen ook door mannen gepleegd (Liem et al., 2013; Liem \& Koenraadt $2008 \mathrm{~b}$ ). Vanuit psycho-evolutionair perspectief kan worden geopperd dat vrouwen niet eenzelfde 'bezitsdrang' richting hun gezinsleden hebben en hun eigen lijden in tijden van echtscheidingsproblematiek, financiële problemen of psychische nood niet uitbreiden naar hun partner en kinderen (zie ook: Daly \& Wilson, 1988).

De overige categorieën doding-zelfdoding zijn erg schaars, zoals doding-zelfdodingen op scholen of openbare ruimten. Dit kan mogelijk worden toegeschreven aan de relatief strikte wapenwetgeving in Nederland vergeleken met andere Westerse landen, waar meervoudige doding-zelfdoding veelvuldiger voorkomt (Fox \& DeLateur, 2013).

Deze studie had tevens ten doel om aan de hand van alle incidenten van doding-zelfdoding tussen 1992 en 2014 te bekijken of er mogelijk sprake is van een copycat-effect. We hebben hierbij gekozen voor een benadering waarin we hebben gekeken naar clusters. In suïcide-onderzoek in navolging van Phillips (1974) door Köpping en collega's (1989) werd gebruik gemaakt van een statistisch model waarin verwachtingen werden berekend voor het aantal zelfdodingen per dag en per maand volgend op de berichtgeving van zelfdodingen. Met ongeveer negen zaken per jaar zijn dodingen-zelfdodingen echter veel schaarser dan zelfdodingen (ongeveer 1800 zaken per jaar; CBS, 2015) en lenen zich daarom niet voor dergelijke statistische modellering. Gezien het relatief klein aantal doding-zelfdodingen, hebben we in onze analyse gekeken naar clusters van zaken. Uit nadere analyse bleek dat zaken die in kort tijdsbestek van elkaar plaatsvonden, veel verschillen op het gebied van de methode waarmee de doding-zelfdoding was uitgevoerd en het onderliggende motief. De tot nu toe bekende resultaten geven geen indicatie voor het bestaan van een copycat-effect onder doding-zelfdoding. Factoren als scheiding, financiële problemen en psychische problematiek vormen dusdanig constante, maar ook diverse factoren, dat tot op heden niet van een copycat-effect gesproken kan worden. Tevens erkennen we dat, theoretisch gezien, copycats kunnen voorkomen vanaf twee cases, ook in tijden waarin het aantal doding-zelfdodingen relatief laag is. Nader kwalitatief onderzoek, bijvoorbeeld door middel van de psychologische autopsie-methode, waarin nabestaanden wordt gevraagd naar de achtergrond van de dader en diens overwegingen (Cavanagh, Carson, Sharpe \& Lawrie, 2003), zal hier mogelijk uitkomst in kunnen bieden.

Ondanks het feit dat we thans niet genoeg aanwijzingen hebben voor het bestaan van een copycat-effect onder doding-zelfdodingen, kunnen we 
de mogelijkheid tot toekomstig imitatiegedrag niet uitsluiten: sensationele, gesimplificeerde en romantiserende berichtgeving over zelfdoding kan leiden tot meer zelfdodingen (Ivonne van de Ven Stichting, 2007). Bij het rapporteren over doding-zelfdoding dienen media dezelfde gedragscodes te hanteren als thans bij zelfdoding gebeurt. Daarbij is het zaak om, zoals de resultaten van dit onderzoek laten zien, doding-zelfdoding te duiden als een complex fenomeen waarin niet één simpele oorzaak aan te wijzen is. Dit onderzoek benadrukt dat zaken die dicht op elkaar volgen niet noodzakelijkerwijs een 'epidemie' vormen, dan wel causaal aan elkaar gerelateerd zijn. Media kunnen daarentegen goede diensten verlenen voor preventie van dergelijke zaken door het publiek te informeren naar hulpdiensten bij psychische, financiële en echtscheidingsproblematiek.

\section{Literatuur}

Barber, C.W., et al. (2008). Suicides and Suicide Attempts Following Homicide. Homicide Studies, $12(3), 285^{-297}$.

Barraclough, B.M. \& Clare Harris, E. (2002). Suicide preceded by murder: The epidemiology of homicide-suicide in England and Wales 1988-92. Psychological Medicine, 32, 577-584.

Berman, A.L. (1979). Dyadic death: Homicide-suicide. Suicide and Life-Threatening Behaviour, 9, $15^{-23}$.

Brants, C.H., \& Koenraadt, F. (1998). Criminaliteit en media-hype: Een terugblik op de publieke beeldvorming rond kindermoord. Delikt en Delinkwent, 6, 542-564.

Cavanagh, J.T., Carson, A.J., Sharpe, M. \& Lawrie, S.M. (2003). Psychological autopsy studies of suicide: a systematic review. Psychological medicine, 33(3), 395-405.

CBS (2015). Overledenen; zelfdoding, diverse kenmerken. Voorburg: Centraal Bureau voor de Statistiek.

Clarke, R. \& McGrath, G. (1992) News Paper Reports of Bank Robberies and the Copycat Phenomenon. Australian \& New Zealand Journal of Criminology, 25(1), 83-88.

Cheng, Q., Chen, F., Yip, P.S. (2011). The foxconn suicides and their media prominence: Is the Werther effect applicable in China? BMC Public Health, $11,841$.

Daly, M. \& Wilson, M. (1988). Homicide. New York: Aldine de Gruyter.

Debowska, A., Boduszek, D. \& Dhingra, K. (2015). Victim, perpetrator, and offense characteristics in filicide and filicide-suicide. Aggression and violent behavior, 21, 113-124.

Denning, D.G., Conwell, Y., King, D. \& Cox, C. (2000). Method choice, intent, and gender in completed suicide. Suicide and Life-Threatening Behavior, 3o(3), 282-288.

Durkheim, E. (1897) 1951. Suicide. London: Routledge.

Elsevier (13 maart 2007). Gezinsdrama's: terughoudendheid media gevraagd.

Felthous, A.R. \& A.G. Hempel (1995). 'Combined Homicide-Suicides. A Review'. Journal of Forensic Sciences, 40, 846-857.

Flynn, S., et al. (2009). Homicide followed by suicide: a cross-sectional study. The Journal of Forensic Psychiatry and Psychology, 20, 306-321.

Fox, J.A. \& DeLateur, M.J. (2013). Mass shootings in America: moving beyond Newtown. Homicide studies, $18,125^{-145}$. 
Frei, A., Schenker, T., Finzen, A., Ditmann, V., Kraeuchi, K. \& Hoffman-Richter, U. (2003). The Werther Effect and Assisted Suicide. Suicide and Life-Threatening Behavior 33(2).

Fu, K.W. \& Yip, P.S. (2009). Estimating the risk for suicide following the suicide deaths of 3 Asian entertainment celebrities: a meta-analytic approach. The Journal of clinical psychiatry, 7o(6), $1-478$.

Haw, C., Hawton, K., Niedzwiedz, C. \& Platt, S. (2013). Suicide clusters: a review of risk factors and mechanisms. Suicide and life-threatening behavior, 43(1), 97-108.

Helfgott, J.B. (2015). Criminal behavior and the copycat-effect: Literature review and theoretical framework for empirical investigation. Aggression and violent behavior, 22, 46-64.

Ivonne Van de Ven Stichting (2007). Suicide in de media. Een richtlijn. Ivonne van de Ven Stichting.

Jae-Hyun, K., Park, E., Nam, J., Park, S., Cho, J., Kim, S., Choi, J., Cho, E. \& Mesoudi, A. (2013). The Werther Effect of Two Celebrity Suicides: an Entertainer and a Politician. PLoS ONE, 8(12), 1-8.

Kivivouri, J. \& Lethi, M. (2003). Homicide Followed by Suicide in Finland: Trend and Social Focus. Journal Scandinavian Study in Criminology and Crime Prevention, 4, 223-230.

Köpping, A.P., Ganzeboom, H.B.G. \& Swanborn, P.G. (1989). Verhoging van suïcide in navolging van kranteberichten. Nederlands tijdschrift voor de psychologie en haar grensgebieden, 44(2), $62-72$.

Leistra, G. \& Nieuwbeerta, P. (2003). Moord en doodslag in Nederland. Amsterdam: Prometheus.

Léveillée, S., Marleau, J.D. \& Dubé, M. (2007). Filicide: A comparison by sex and presence or absence of self-destructive behavior. Journal of Family Violence, 22(5), 287-295.

Liem, M. (2010). Homicide followed by Suicide. An empirical analysis. Utrecht: Universiteit.

Liem, M. \& Koenraadt, F. (2007). Homicide-suicide in the Netherlands: A study of newspaper reports, 1992-2005. The Journal of Forensic Psychiatry \& Psychology, 18(4), 482-493.

Liem, M. \& Koenraadt, F. (2008a). Filicide: A comparative study of maternal versus paternal child homicide. Criminal Behaviour and Mental Health, 18(3), 166-176.

Liem, M. \& Koenraadt, F. (2008b). Familicide: a comparison with spousal and child homicide by mentally disordered perpetrators. Criminal Behaviour and Mental Health, 18(5), 306-318.

Liem, M., Koenraadt, F. \& Hengeveld, M. (2009). Kinderdoding gevolgd door een ernstige poging tot zelfdoding. Tijdschrift voor Criminologie, 51(3), 262-276.

Liem, M. \& Leissner, N. (2016). 'Dodelijk geweld'. In: Liem, M. \& Muller, E. (red.) Geweld en geweldsbeheersing. Deventer: Kluwer.

Liem, M., Levin, J., Holland, C. \& Fox, J.A. (2013). The nature and prevalence of familicide in the United States, 2000-2009. Journal of family violence, 28(4), 351-358.

Liem, M. \& Nieuwbeerta, P. (2010). Homicide Followed by Suicide: A Comparison with Homicide and Suicide. Suicide and Life-Threatening Behavior, 4o(2), 133-145.

Liem, M. \& Oberwittler, D. (2013). Homicide followed by Suicide in Europe. In Liem, M. \& Pridemore, W.A. Handbook of European Homicide Research. Patterns, Explanations and Country Studies (197-216), Springer.

Liem, M. Postulart, M. \& Nieuwbeerta, P. (2007). Moord-zelfdoding in Nederland. Een epidemiologisch overzicht. Tijdschrift voor Veiligheid, 2(6), 16-36.

Liem, M., Smit, P., Wilsem, J. van \& Nieuwbeerta, P. (2012). De daling van moord en doodslag in Nederland. Tijdschrift voor Criminologie, 54(1), 18-32.

Marleau, J.D., Poulin, B., Webanck, T., Roy, R. \& Laporte, L. (1999). Paternal filicide: A study of 10 men. Canadian Journal of Psychiatry, 44, 57-63.

Marzuk, P.M., Tardiff, K. \& Hirsch, C.S. (1992). The Epidemiology of Murder-Suicide. Journal of the American Medical Association, 267, 3179-3183.

Messing, J.T. \& Heeren, J.W. (2004). Another side of multiple murder. Homicide Studies, 8, 123-158. Niederkrotenthaler, T., Till, B., Kapusta, N.D., Voracek, M., Dervic, K., Sonneck, G. (2009). Copy- 
cat-effects after media reports on suicide: a population-based ecological study. Social Science \& Medicine 69, 1085-1090.

Nieuwbeerta, P. \& Leistra, G. (2007). Dodelijk geweld. Moord en doodslag in Nederland. Amsterdam: Balans.

Panczak, R., Zwahlen, M., Spoerri, A., Tal, K., Killias, M. \& Egger, M. (2013). Incidence and risk factors of homicide-suicide in Swiss households: National cohort study. PloS one, 8(1), e53714.

Phillips, D.P. (1974). The Influence of Suggestion on Suicide: Substantive and Theoretical Implications of the Werther Effect. American Sociological Review, 39, 340-354.

Saint-Martin, P., Bouyssy, M. \& O’Byrne, P. (2007). Homicide-Suicide in Tours, France (2000-2005) - description of 10 cases and a review of the literature. Journal of Forensic and Legal Medicine, 15, 104-109.

Salari, S. \& Sillito, C.L. (2016). Intimate partner homicide-suicide: Perpetrator primary intent across young, middle, and elder adult age categories. Aggression and Violent Behavior, 26, 26-34.

Schmidtke, A. \& Häfner, H. (1988). The Werther effect after television films: new evidence for an old hypothesis. Psychological Medicine, 18, 665-676.

Sturup, J. \& Granath, S. (2015). Child homicides in Sweden: A descriptive study comparing the 1990 and the 200os. Homicide Studies, 19, 175-187.

Starzomski, A. \& D. Nussbaum (2000). 'The Self and the Psychology of Domestic HomicideSuicide'. International Journal of Off ender Therapy and Comparative Criminology, 44, 468-479.

Swatt, M.L. \& He, N. (2006). Exploring the Difference Between Male and Female Intimate Partner Homicides Revisiting the Concept of Situated Transactions. Homicide Studies, 10(4), 279-292

Wasserman, I.M. (1984). Imitation and Suicide: A Reexamination of the Werther Effect. American Sociological Review, 49, 427-436.

West, D.J. (1965). Murder followed by suicide. Cambridge, MA: Harvard University Press.

Wijfjes, H. (02-05-1997). 'Pleidooi voor mediastilte eenzijdig'. De Journalist.

Wijngaarden, E.J. van, Leget, C.J.W. \& Goossensen, A. (2015). Till Death Do Us Part: The Lived Experience of an Elderly Couple Who Chose to End Their Lives by Spousal Self-euthanasia. The Gerontologist, 1-11.

Wilson, M., Daly, M. \& Daniele, A. (1995). Familicide: The killing of spouse and children. Aggressive Behavior, 21(4), 275-291.

\section{Over de auteurs}

Marieke Liem is senior onderzoeker bij het Institute for Security and Global Affairs en hoofd van het Violence Research Initiative aan de Universiteit Leiden. Haar onderzoek richt zich op diverse vormen van fataal geweld in binnen- en buitenland.

E-mail: m.c.a.liem@fgga.leidenuniv.nl

Natascha van Keeken volgt de master Forensische Criminologie aan de Universiteit van Leiden. Haar scriptie heeft ze geschreven over profielen van West-Europese uitreizigers in Syrië. Ten tijde van dit onderzoek liep ze stage bij het Violence Research Initiative.

E-mail: nd_vankeeken@hotmail.com 
